\title{
Marketing research and integrated marketing communication plan of Oreo
}

\author{
Md Farhan Masud \\ a MDFARHAN.MASUD47@bcmail.cuny.edu \\ Department of Business Administration, The City University of New York, Brooklyn College 21502 Hillside Ave, Queens Village, NY \\ 11427, USA
}

\begin{abstract}
There are few international companies with a high level of customer interaction from digital platforms. An example of this is the Oreo Cookie, which with its combination of ingenuity, smartness, and engagement with consumers, has managing to retain an increasing number of people on its various online platforms, but which has also received a mostly positive reception. This business shows that the opportunity to react to emerging developments and incorporate multiplatform technology enables users to impact new and creative messaging and $\mathrm{m}$ in more than 100 years of cookies history. Mondelēz has more than 40 plants worldwide, and its center of excellence for producing chocolate is in Brazil, a country that will export the product to the USA. The Brazilian plant can ship to 10 countries, such as Argentina, the United States, Chile, Morocco, Costa Rica, and Colombia. The company has more than 800,000 points of sale, and, in a first-year, Oreo chocolate could reach 700,000 of these commercial spaces. The company has adapted to the market not to affect its operation, also the case with the energy reform enacted in the current trends. It includes promoting healthy lifestyles, product innovation, responsibility in advertising issues, and leadership in the communication of balanced diets that include snacks that brought taxes on sweets such as chocolate due to their high caloric content. One of the aspects that characterize a successful brand is the fact that other brands want to ally with it and, through co-branding strategies, launch products that, in a certain way, allow them to leverage their reputation and fame to reposition or reinforce their positioning. These are also the logical benefits of allying with a widely accepted brand in terms of the sales potential and the attractiveness generated in the category by putting a product, a widely recognized label, apart from saying that this rule fulfills in a brand Oreo. Over time, Oreo has become one of the most famous snacks worldwide that helped create new products. It could either be on its own or from the same alliances; we talked about taking advantage of their cookie's successful concept and knowing how to adapt it to other similar or substitute products. However, beyond all the success that has preceded it today, people's great affection towards this brand includes children to the elderly. Many do not know is that its history contains a certain air of controversy that shows that not everything has been rosy throughout the more than one hundred years it has been on the market. Even so, throughout much of the 20th century and so far into the present, the brand has managed to keep this situation at bay and prevent it from directly impacting its image to the point that many are unaware of this issue. It has become a beloved brand in different places and countries present through very well-executed marketing.
\end{abstract}

Published by IJRP.ORG. Selection and/or peer-review under responsibility of International Journal of Research Publications (IJRP.ORG) 


\section{Executive Summary}

What makes Mondelz the most known snack manufacturer in the world the multinational corporation is not about its emblematic brands and products. The example of this cookie brand works serves as the best example of how a classic brand can adapt to the new times. For many years, even decades, certain brands have established themselves in the family product niche. They were those kinds of products that were bought for the children, which was no longer relevant in an adult's shopping basket. Everyday products could not stay that the market niche had a particular point of ephemerality once your consumer grew, they were lost forever, but this has changed in recent years. Social and demographic changes have impacted the market and blurred the boundaries of which things are being sold to. Consumers are no longer so limited on what they can buy. The power of nostalgia has become an engine of consumption, which dumps consumers in their childhood flavors, and brands also want to have adult and affluent consumers. Oreo cookies, a few years ago, we assumed were directly to buy and give to the little ones and that now, however, also reach the adult niche. Not only that: they have managed to get different markets and different gastronomic cultures, going beyond their call of birth and their original place. But they also developed consumer trust with the stakeholders as well. This faith and the dignity of their daily operations are upheld to make the business operation and strategy in the right direction. Brands and celebrities who genuinely wish to attract the audience with their messages must separate themselves from the rest of the messages which bombard them. Most notably, they would still do this by ensuring they are genuinely enforced. Only then will the shift really will not be created. Today, there is a strong emphasis on food businesses to pursue more efficient supply and manufacturing practices. In this period, only Mondelēz, the company that manufactures Oreos, has announced that its signature cookies will use organic Cocoa only. Via its cocoa development scheme, Cocoa Life, we can use Cocoa from organic growers. The organization expects that this path will allow them to extend their procurement activities rapidly based on environmental sustainability. The organization hopes that this path will allow them to expand their environmentally sustainable procurement activities quickly. Cocoa Life was developed to support farmers in an eco-friendly manner to grow Cocoa. The organization teaches organic farming methods that work to mitigate climate change. Via this method, cocoa production is improved, and depleted forests are controlled and rehabilitated. The software also lets communities tailor their strategies while preserving the local ecosystems to enhance their small businesses. Oreo is Mondelez's premium brand and has made history with its real-time marketing actions. The Oreo customization project was quickly turning into something much bigger, an opportunity for the brand to play a role in significant events in customer's lives, which would be remembered for life.

\section{Industry: Background and Situation Analysis}

There are few international companies with a high level of customer interaction from digital platforms. An example of this is the Oreo Cookie, which with its combination of ingenuity, smartness, and engagement with consumers, has managing to retain an increasing number of people on its various online platforms, but which has also received a mostly positive reception. This business shows that the opportunity to react to emerging developments and incorporate multiplatform technology enables users to impact new and creative messaging and $\mathrm{m}$ in more than 100 years of cookies history. Mondelēz has more than 40 plants worldwide, and its center of excellence for producing chocolate is in Brazil, a country that will export the product to the USA. The Brazilian plant can ship to 10 countries, such as Argentina, the United States, Chile, Morocco, Costa Rica, and Colombia. The company has more than 800,000 points of sale, and, in a first-year, Oreo chocolate could reach 700,000 of these commercial spaces. The company has adapted to the market not to affect its operation, also the case with the energy reform enacted in the current trends. It includes promoting healthy lifestyles, 
product innovation, responsibility in advertising issues, and leadership in the communication of balanced diets that include snacks that brought taxes on sweets such as chocolate due to their high caloric content. One of the aspects that characterize a successful brand is the fact that other brands want to ally with it and, through cobranding strategies, launch products that, in a certain way, allow them to leverage their reputation and fame to reposition or reinforce their positioning. These are also the logical benefit of allying with a widely accepted brand in terms of the sales potential and the attractiveness generated in the category by putting a product, a widely recognized label, apart from saying that this rule fulfills in a brand like Oreo. Over time, Oreo has become one of the most famous snacks worldwide that helped create new products. It could either be on its own or from the same alliances; we talked about taking advantage of their cookie's successful concept and knowing how to adapt it to other similar or substitute products. However, beyond all the success that has preceded it today, people's great affection towards this brand includes children to the elderly. Many do not know is that its history contains a certain air of controversy that shows that not everything has been rosy throughout the more than one hundred years it has been on the market. Even so, throughout much of the 20th century and so far into the present, the brand has managed to keep this situation at bay and prevent it from direct impact on its image to the point that many are unaware of this issue. It has become a beloved brand in different places and countries present through very well-executed marketing.

\section{Company: Background and Situation Analysis}

The snack food industry has become a very competitive landscape, with all sorts of decadent and frequent treats. More and more people consume snacks between meals and even as substitutes for them regardless of their consumption. Today's consumers seek convenience in consuming their snacks; these are present when and where they want to finish them. Therefore, in 2020, technologies such as automation and different forms of delivery will continue to emerge. In this sense, technology will be strategic to satisfy the consumer, but it will also help brands know and control consumer demand in real-time and create personalized options. Consuming healthy snacks is taking a step further functional snack. Finally, and putting sustainability at the center, today, consumers demand that their packaging be recycled, compostable, or returned, so this is the great challenge we face. Via a merger of several regional banking firms, the National Biscuit Company was founded in the USA in 1898.

In 1952, on the upper left corner of National Biscuit Company, goods first appeared the now-famous red Nabisco triangle. In 1971 Nabisco was renamed the Biscuit Company. Nabisco, Inc. fused into Nabisco brands in 1981 with Regular Products, founded in 1929. Philip Morris Co. extends its global footprint and enhances its role in the rapidly rising snacks market. Philip Morris' purchased Nabisco Holdings in December 2000. For $\$ 14.9$ billion in cash plus $\$ 4$ million in debt, Philip Morris bought Nabisco (Grant, 243). Based on retail revenue, Nabisco is the world's leading cookie maker and marketer. Philip Morris finally merged its Kraft Food operations with the Nabisco brands. Philip Morris founded a new holding firm, known as Kraft Foods Inc., in March 2001.

Because consumers' buying habits were shifting towards lower-calorie, the sales of cookie sales began to decline slowly In the 1990s. When more brands began making low-fat products, then sales began to increase gradually again. At the beginning of the 2000 s, the low-fat wave was growing. These diets do not prohibit the ingestion of "healthy" fats but promote them in reality. Companies have been obliged to develop a broad selection of goods with little or no fat to retrieve old customers and retain new consumers. Many businesses manufacture their products in reduced fat / fat variants (Hasibuan, 2015).

Biscuits, including brands such as Oreo are supplied to the business, Chips Ahoy! Nabisco, and Nilla, among others, were mostly stable in the U.S. and abroad, relative to last year in the first three months of 2020. 
Fight always against the cost-effective Chips Cookie Ahoy range and other cookies offering actual, natural ingredients. The addition of chemical additives over the years. Some new changes, including dark chocolate to the standard cocoa cookie, to old classics to reflect consumption. If they mean positive thoughts to Pepperidge Farm from its buyers by 'goodwill,' you cannot offer a similar cookie (Cabaas, 1992). Pepperidge Farm is the type of business that challenges rivals for absurd motives. Oreo revenue rose by over $60 \%$, the highest development among the world's entire leading cookie products distributed in the US. In this sense, it is essential to remember that during the same period, cookie sales grew by just $10 \%$ over the industry or that more than $7 \%$ of this increase primarily attributed to rising demand for Oreos (Hasibuan, 2015). Globally, Oreos are also dominant. A company that constitutes nearly $5 \%$ of the worldwide sales of cookies has more than three times the other product's footprint.

A PESTEL analysis of a tool used to identify the macro (external) forces facing an organization. In this case, of Oreo, the PESTEL analysis would be following

\section{Political}

Mondelez, the manufacturing firm for Oreo, has released a statement illustrating its concern for policy uncertainties in its regions. Explicitly, its CEO said that raised trade tariffs, the UK's ongoing move to withdraw from the EU, global recession, and financial inclusion in China, among others, could harm both Mondelez and its Oreo stock (Guo, Lu, Sheng \& Yu, 2018). President Donald Trump claimed that he had stopped eating Oreos after the parent corporation moved one of their facilities from the USA to Mexico. The decision of the United States to provide a modified financial transaction tax with Mexico has a minor impact on its revenue. It may also lead other states to impose restrictions on trade that may further affect Oreo's profits by taking anti-globalization steps introduced by the US administration.

\section{Economic}

The economic situation is declining dramatically in earnings for Oreo. The price fluctuations in raw materials, such as chocolate, grain, or glucose, etc., are among the significant factors influencing Oreo's production. Thus, in Brexit, the fresh import tariff and the more fragile supply chain will significantly affect Oreo's profits and benefit. Any price hike can result in an increase or a reduced cost for Oreo. The company has said that after 12 months, Cocoa has fluctuated, which is one of the most significant inputs needed for Oreo cookies. In comparison, the UK sector contributes a large portion of Oreo's sales

(Hasibuan, 2015).

Social

Children and teenagers aged 6-18 years are the primary consumers of Oreo Cookies. Oreo has an immense variety of commodities. Many of the school children tend to eat high-cocoa biscuits and candy. Therefore, Oreo must take care of their children's tastes before introducing new products or improving the established outcomes. However, as the consumer's eating patterns shift quickly, Oreo should follow its consumers' preferences and perform controlled market studies. With more information about less sugar, people will continue to change their cookies from those filled with sugar to healthy cookies. More than $180+$ items are available to date. The vast portfolio helps attract a wider audience and sell their customers' different cookies to please their taste buds. Then, while retaining the color, Oreo can decrease its flagship products (Bublitz \& Peracchio, 2015).

Technological 
Generally, technology provides Oreo with more resources to expand its client base and retain more sensitive knowledge to make it vulnerable to cyber-attacks. Because the third party is responsible for the bulk of Oreo IT and operating operations, it is susceptible to cyber threats, leading to a breach of the organization's vital information. Companies market through broad e-commerce channels with the implementation of ecommerce (Levine, 1999). A timely move towards data management and daily data backups is essential to carry out. Oreo will have to negotiate with its machine suppliers to raise the costs further. Any attacks of ransomware on the devices will end. In 2017, there was one such event, in which a virus contaminated Oreo's sales of the systems.

\section{Environmental}

Deforestation because of palm oil production is the primary concern of the environmental footprint of Oreo. Nevertheless, by withdrawing 12 of its supply chain firms, the company took steps to reverse the damage. These woods have been used by the organization to procure palm oil for its goods. The company manufacturing Oreo was liable for the clearance of over 700 square $\mathrm{km}$ of forest land in Indonesia's rainforests. Mondelez. Soon the organization should begin to find alternatives not to use the palm oil plantations because news can affect Oreo's global sales (Monteiro, Gomes \& Cannon, 2010).

Legal

In the past, a federal prosecutor has lodged a lawsuit in a dispute against Oreo that claims it uses a massive quantity of Transfat to produce its hazardous cookies to human health. In September 2018, Hydrox, the largest rival, accused it of sabotaging his market share through unethical and abusive activities. Despite that, Oreo has retained a strong brand reputation until now. While accusations were made, any evidence did not back them. Hydrox posted a message on its official site on Facebook that salespersons are attempting to conceal their cookies from the store's shelf to exclude the rival from the market.

\section{Indirect Competitor Snickers (Mars Inc.)}

There has been a constant revolution in the changing world of famous chocolates and sweets in recent years (Wiist, 2011). Sweets and chocolate bars have existed for several years in roughly the same shape. Today, however, discerning contemporary buyers are still looking for innovation and improvement. Customers have become the engine behind product transition; for example, Snickers has undergone various changes in recent years. Snickers had implemented pure standard flavors, textures, and packaging by the late 1980s. Kit Kat is the top-selling chocolate bar in Great Britain. Yet consumers' preferences are continually evolving in the dynamic world (Hult \& Ketchen, 2017). To maintain their popularity and remain on top, even the most famous icons need to reinvent themselves from time to time. Pop stars, for example, adapt their pictures, video animators modify the personalities of their favorite cartoonists, and car designers reinvent childhood classics such as the VW Beetle and the Micro.

The old brand should hold enough to retain current product lovers' interest and make more creativity to draw a whole new generation of customers. One trick is a success. Oreo's supremacy has several explanations. The most prominent example of the attraction is Oreo's everyday use to boost other products (Monteiro, Gomes \& Cannon, 2010). After all, the treat is nevertheless engulfed in milk or coated but is brown with dough, blended with ice cream, blended into milkshakes, smashed, and poured over many treats. This case illustrates a complete re-evaluation of an existing Oreo brand's product, pricing, packaging, communication, and distribution strategy in an international market. For most of its 100 -year existence, Oreo was consistently America's best-loved cookie, but today it is a global brand. It can also explore the global versus local mix needed for success in an international market and illustrate the strategies necessary to succeed in emerging markets like India and China. Faced with stagnation in the domestic market, Kraft Foods moved it into 
emerging markets. It made some mistakes, learned from them, changed its strategy, and ultimately triumphed in winning over customers.

In dynamic global economies, Oreo uses diverse tactics to succeed. The marketing blend and marketing research techniques are included. Business goals include expanding to increasingly changing markets and economic sectors. In Asian markets with economic growth, Canada, and America, Oreo goods have been increased. The increasing population on target markets gave the Oreo branded goods a vast demand (Wiist, 2011).

Targets

- Creative product development.

- Oreo's brand and revenues continue to expand.

- Restore Oreo brand position and reaffirm its shape

- Local marketing setup.

\section{SWOT Analysis of OREO}

The SWOT analyzes are a strategic analysis tool to help a company recognize competitive market strengths, vulnerabilities, openings, and risks. Strengths and vulnerabilities are often interrelated, while rewards and risks are often external.

Strength of Oreo:

- The Oreo has the best customer loyalty in the same line of product (ETBrandEquity.com, 2020)

- In more than 100 countries, Oreo cookies were available ("Our brands | Mondelēz Int," n.d.).

- It has been spread across several marketing and distribution platforms worldwide.

- Oreo is one of the best products known for its solid logo style (ETBrandEquity.com, 2020).

- Brand consumers prefer Oreo to cookies for the brand (ETBrandEquity.com, 2020).

Weakness of Oreo

- Chocolate is the raw material for Oreo cookies. The raw materials cost is low, but the company cannot raise the commodity (Research \& Markets, 2018).

- There are many types of biscuits on the market, all of them without strong consumer differentiators (Palumbo and Herbig, 2000).

- Oreo create obesity in children is rich in weight and calories (Palumbo and Herbig, 2000).

Opportunities of Oreo

- Increased demand for cookies among teens and children (Mintel, 2012).

- $\quad$ Oreo will offer many flavors to start (Mintel, 2012).

- The corporation Oreo is willing to invest; in business and diversity in other business fields (Confectionerynews.com, 2020).

Threat of Oreo

- $\quad$ Diabetes and other health diseases reduce the demand for snacks (Gittelsohn \& Trude, 2017).

- There are multiple market players with the same product and same quality (Gittelsohn \& Trude, 2017).

\section{Company: Background and Situation Analysis}

Mondelez International has its roots in the National Dairy Products Corporation, founded on December 10, 1923, by Thomas H. McInnerney. The company was formed to execute a build-up strategy in America's fragmented ice cream industry, and with acquisitions, expanded into the full range of dairy products. 
McInnerney operated the Hydrox Corporation, a Chicago ice cream company. In 1923, he went to Wall Street to ask investment bankers to finance his plan to consolidate America's ice cream industry. McInnerney initially encountered resistance, with a banker discrediting the dairy industry. He persevered, convincing a consortium (including Goldman Sachs and Lehman Brothers) to fund an accumulation strategy. As a result, National Dairy was formed by the merger of McInnerney's Hydrox with the Rieck McJunkin Dairy Company of Pittsburgh. The company was listed on the New York Stock Exchange, with its initial public offering of 125,000 oversubscribed shares (Levine, 1999). Target market and international brand sales: Analysis of the contingent position of nation-market characteristics.

Oreo was the sort of snack that the U.S. customer community desired (Wiist, 2011). The Oreo comprises of 2 firm chocolate chip cookies, somehow identical to one of its previous items, "The Bouquet," that is rich in vanilla frosting. The first Oreos were slightly more prominent but still round than the product today. The name's root is unknown, but it was likely a Greek Oreo, which means hill or mountain. Oreo, which looked like an English biscuit, became an excellent seller among the NBC sandwich. This is because A.W. has some merit. Green's propensity to classical names [the executive company]. Oreo was officially recorded as Oreo Biscuit in 1913; by 1921, it became "Oreo Sandwich,"; and by the year 1948, it became "Oreo Creme Sandwich." National Dairy proliferated through many acquisitions, typical of an accumulation strategy. The additions were primarily for National Dairy stocks rather than cash. The company acquired more than 55 companies between 1923 and 1931, including:

\begin{tabular}{|l|l|l|l|}
\hline Year & Company & Sector & Location \\
\hline 1924 & WE Hoffman & Ice cream & Pennsylvania \\
\hline 1925 & Dunkin Ice Cream & Ice cream & Illinois \\
\hline 1925 & Sheffield Farms & Liquid milk, ice cream & New York \\
\hline 1926 & Breyers Ice Cream & Ice cream & Pennsylvania \\
\hline 1928 & Breakstone brothers & Liquid milk, cheese & New York \\
\hline 1928 & General Ice Cream & Ice cream & New York, East Coast \\
\hline 1929 & Hiland Dairy & Liquid milk & Kentucky \\
\hline 1930 & Kraft-Phenix & cheese & USA, international \\
\hline 1931 & Consolidated Dairy Products & Ice cream, other dairy products & New York, New \\
\hline
\end{tabular}

Mondelez International work in over 80 countries, and they have about 80,000 staff in their research and development facilities, plants, offices, and delivery operations worldwide. Mondelez International mainly produces and sells sweets, including chocolates, candies, cookies, and assorted cheese and fruit products and drinks. Mondelez International is one of the world's leading snack industries, with net sales totaling \$25.4 billion. The company has an operation in five segments The Asia Pacific, Europe, Middle East, Eastern Europe, North America, and Africa. Oreos is sold internationally and is still growing worldwide (Wiist, 2011).

\section{Brand: Background and Analysis}


Mondelez had distribution facilities on several continents in 2016. In Morocco, for example, Oreos planned for the African market. Environmental organizations have condemned the use of palm oil arising out of deforestation, tourists' service, and social manipulation cookies. Oreo's marketing firm Kraft Foods has extended its reach around the world since 2009, following the purchase of Nabisco (in 2000) and the absorption of Mondelez (2012) and in 2010, with significant ads in France, in which Triomphe Snat's brand has been little established for ten years. More than 500 billion Oreos have been produced since its creation, and Oreo has been the biggest seller of the last century. A special agreement was signed in 2017 between Alphabet, Google's parent company, which makes Android, and Oreo: the eighth edition of the Android Smartphone operating system after Android Nougat was branded Android Oreo. Without a money connection, this promotional trade occurs, one of the two goods profiting from its credibility. Both firms intend to conduct cooperative road marketing activities (Olson et al., 2018). Besides the famous cookie, The Oreos were then reduced to assorted shapes and flavors, white chocolate, milk chocolate, peanut butter, mini-cookies, the Easy as a crunch of Mix Mania, the McDonald's as a crunch of McFlurry, the Burger King's King Fusion as an ice bar, chocolate-free, bananas, tube, turnover, etc. The receipt for these cookies was also amended for short for its fiftieth anniversary. Oreo always follows the market trend and adopts a new and flexible policy that keeps its brand value contemporary after hundreds of years of inauguration.

Oreo reacts to trends by launching multiplayer games like the Double Stuf Racing League with celebrities in sports. He also released special edition cookies, such as the Rio film's blue cream filling. The cookie kit featured magnets and customers who received minor and big prizes for the entire stamp album. The promotion took place in Colombia, Peru, and Ecuador for one year. The company launched numerous unique commercials, including the rainbow-colored Oreo sandwich, which will support the 2012 LGBT Pride Month (Sacks, 2014). The series went on to celebrate Bastille Day with a red, white, and blue filling. For Shark Week, a particular ad featuring an Oreo cookie with a jagged bite was on display at Discovery Channel. On social media sites, the brand maintains accounts. More than 38 million users are followed on Facebook alone. The international recognition of Oreo's sandwich cookie is worth learning. Marketers worldwide could learn a lot from Oreo's adaptation (Olson et al., 2018). The brand has developed many product and marketing campaigns via its penetration into different international markets to ensure its domination of the market and make Oreo a local customer's favorite (Sacks, 2014). A few brands came to the emerging international markets with their achievements.

\subsection{BCG Matrix: Oreo}

The Product Portfolio Matrix (BCG Matrix) of the Baston Advisory Group is intended to facilitate its longterm strategic strategy by analyzing its product portfolios to assess when they can spend, quit, or grow products. The Growth / Share matrix is also known. In the target audience, Oreo cookies did not create a large market. Consequently, Oreo's revenue was not high, and the biscuit (Cabaas, 1992) mainly produced its profit. Cost and schedule investment in this sector will help the business achieve more outstanding market share and profits as the industry expands and can expand more. Thus, Oreo is classified as the BCG matrix Query Sign.

\subsection{Porter's competitive strategy analysis in Oreo brands}

The threat of entry:

Current existing Oreo brands have been in constant threat to new market entrants with Oreo brands with strong awareness, like China, Canada, the United States, Indonesia, Japan, and Mexico. The rising demand for foodstuffs due to the worldwide swelling has drawn prospective buyers to the industry. In general, new food 
entrants' threat is severe and spreads to cookies, biscuits, and such like (Castrodale, 2018). This is due to the limited initial resources needed to start up a food production facility.

Power of suppliers:

Raw material and labor sources are diversified, and their control has been significantly diminished. The products can be obtained conveniently, for example, milk and sugar, available from different suppliers, and a high supply (Castrodale, 2018). The changeover between vendors is virtually negligible, and there are several alternative supplies required for manufacturing Oreo products. Inputs, particularly in the production of Oreo chocolates and biscuits, are highly differentiated. The vendor size is comparatively small, giving the firm more dependence on the best supplier such that its power is reduced.

Power of Buyers:

The capacity of purchasers is very high since the food industry has low switching costs. Food shoppers are typically susceptible to price changes that make customers affect commodity costs. They will quickly move to competitive goods, which is why brands need to be established, and customers' loyalty developed (Chacon, Letona \& Barnoya, 2013). However, significant numbers of Oreo buyers and market segmentation have led to a decline in buyers' strength.

Substitutes:

The low cost of replacement goods accompanies this. Oreo's brand name and customer loyalty are needed to sustain good product performance. Oreo goods offer several inexpensive alternatives from dairy powder, chips, and cookies. Increased market consolidation has resulted in low development prices, rising food demands, and low sector exit rates. Market competition is relatively intense, with Keeler, the second largest in the U.S., seeing a substantial increase in revenue and a broad diversification in product inventions (Hasibuan, 2015). However, Oreo brands' success in the global market has maintained its brand image and product distinction. In this sector, there is a healthy business competition.

\section{Product}

Oreo is a globally renowned food. Since 1912, the Oreo has rendered the sandwich as a bar. Oreo has been an international phenomenon from the beginning as a small company. In the last 100 years, Oreos have achieved great popularity. Oreos are now available in more than 100 countries and are increasing internationally. Oreos are marketed in the United States, Europe, the Middle East, Africa, and Australia. Oreo is working well before growth to study new global markets (Kanten \& Darma, 2017).

Oreo reflects on its customers' geographic, social, and economic disparities and how this affects customer procurement. The technique of Oreo is ideal for customers worldwide (Kanten \& Darma, 2017). Oreo understands how to sell to its customers by paying particular attention to location, product, packaging, and promotions. The brand campaign of Oreo is how Oreo has the world's number one cookie reputation. Oreos is distributed internationally and is now expanding worldwide. A comprehensive global marketing campaign was used with the famous cookie.

In the strategy for emerging world markets, globalized businesses use ads and product developments. They examine the variable position of country market characteristics in the Marketing Mix journal and brand revenues in global markets. Although delivery and pricing have the most excellent effect in emerging and developed countries, respectively, the impacts in emerging markets in product production and advertisement are substantially more significant than in developing countries' (Loy, Rohde \& Corley, 2019). Oreo is mindful that price and delivery may not necessarily be the primary consideration when planning to penetrate foreign 
markets. To manage current and future global growth, Oreo uses a marketing blend, including commodity identification, advertising, and promotion. Another tactic is to build consumer loyalty to discourage consumers from moving to competing goods. This is to satisfy various regional criteria, particularly about the tastes and packaging for products and services. Geographical and demographic segmentation of the goods' for different locations, the firm sells multiple Oreo products. Another group of targets is women who appear well mindful of their wellbeing, and for this consumer demographic, the organization has adopted fat-free Oreo products. That was done by constructing labels and introducing discounts for particular segments of the market, including girls. The demonstration goals for biscuits and cream-filled goods are largely adolescence (Monteiro, Gomes \& Cannon, 2010).

The Oreo is a globalized commodity well recognized. Oreo's brand campaign is how Oreo keeps the world's number one cookie reputation (Russell, 2012). The technique of Oreo is ideal for customers worldwide. Since 1912, Oreo, like a cookie, has made the sandwich. In the last 100 years, Oreos became incredibly popular. Oreo pays attention to how this can affect customer procurement in terms of geographic, social, and economic disparities among its customers. Oreo understands how to sell to its customers by paying particular attention to locations, goods, advertising, and promotion. Until growth, Oreo has done excellent research on emerging world economies. Oreo became a global phenomenon as a respectable company (Russell, 2012).

\section{Price}

The pricing target of Oreo is the setup of the optimum pricing strategy. It can be complicated and full of competing targets, including boost delivery rates, increase revenue, raise profit margins, and grow new business segments (bdc.ca, 2020). External variables, such as the economy, need to be evaluated. Besides the market's needs and challenges, the price thresholds should also be defined, where the demand is multiplying. Therefore, competitors aid when selecting a plan with experience of the pricing strategies and price variations of three or five significant competitors (Lisa, 2018). Thus, the buyer can know the risk of the investment-how much value if they do not buy. Oreo should examine internal considerations such as consumer profit after realizing this. The gain perceived must be carefully evaluated. It would only be necessary for those who will see how vital the service is for the consumer and why. Oreo requires three requirements. These are absolute will, real impartiality, and the requisite expertise in this complex issue to incorporate price strategies in the practical implementation. The path to speed must be calculated first. For this reason, deadlines are specified. Price is the cost to consumers of the commodity. Collection duration, loan duration, allowances, and discounts are included. Profits go at the right price for the people. The prices of Oreo but not so much lowers than its counterparts. For example, Oreo's daily bundle was $20 \%$ cheaper than Popular Amos and Oreo butter cookies, $10 \%$ less expensive than other niche rivals like Royal Danish butter cookies were. Yet Starbucks was pricier than fast-service restaurants. The above is $17 \%$ cheaper on average compared to Starbuck with Big Apple doughnut and Coffee (Lisa, 2018). For busy individuals, grocery stores are far more comfortable. Retail outlets can opt to target consumers in the rural region and other areas to increase brand recognition (Morgan, Whitler \& Chari 2019). Besides, the shop's atmosphere can affect crowds too. Instead of a busy, dirty shop, people want to spend their time in a quiet environment. To make its customers delight with its offerings, the company can deliver and serve its customers well (Lisa, 2018).

\section{Place}

The commodity was unveiled on the Canadian market in 1948. However, with proper placement, Oreo sandwich cookies have worldwide recognition. Several labels entered international foreign markets with their 
accomplishments. The company has developed a wide range of products and marketing campaigns through its commitment to diverse global markets to retain its market share and make Oreo a local consumer favorite. In very early Latin America and Central America, Mondelez launched Oreo cookies in 1928. The achievements of Oreo's evolving worldwide could teach marketers a lot. In several markets, Oreo's accomplishment is "from the filling." It contains three types of variations of chocolate for the Mexican market. It provides bananas and milk cream filling for Argentinean consumers. Several supplying products, including cherry, strawberry, peach, raspberry, peach, and cranberry, are available in Asia. In Indonesia, it launched a chocolate and stew duo.

Differentiated promotion, though, is often very pricey. The organization has higher costs as new goods are vital to meet each target market (Zuhdi et al., 2020). An independent product and business sector have its marketing and delivery plans: innovative communications, strategies, incentives, and investments. Costs will quickly add up as many specific consumer markets are pursued. The expenses method promotion is worth a big business, such as Kraft, since its product is distributed worldwide. Oreo is now pursuing a well-designed marketing campaign that will use a marketing blend to meet its target market's expectations and desires to increase exposure and develop them as the most popular and respected brand on the planet and its target market. Item, price, position, and marketing plans are a co-ordinate action strategy. Each part allows consumers to control product placement. Store the marketer with a nice store, tank station, and the rest stop more of the items (Reddy, 2014). In each region, there are processing facilities for various Oreo products that fulfill consumer needs and sensitivities.

As part of its marketing mix distributive approach, the sales and marketing staff ensure that the product is distributed via the correct distribution channel. Oreo has been found in selected 100 countries worldwide. It has been reported. In India, shopping malls, malls, mom and pop shops, retailers, etc. The usability of the commodity globally, covering both rural and urban areas, has been increased. It is part of the conventional system that sells any one of these items. For making goods affordable to customers, Oreo uses Mondelez's broadly run network (Reddy, 2014).

Location means that the commodity holds a simple, distinctive, and attractive role in target buyers' eyes concerning competitive goods. If the product is undoubtedly the same as others, the buyer will not justify purchasing it if it wishes to establish a unique market advantage for their goods (Oreo, 2020). Oreo goods are thus usually viewed by their ads with a high-level image. Customers can pay for these goods for their highquality products and different preferences.

\section{Promotion (Advertising and Social Media)}

For Oreo, the promotional challenge is finding ways to encourage potential consumers with their new offerings. But they had to conduct extensive market research and precisely Oreo's marketing strategy before they could implement this step. Thus, they will understand the business's equity, its assets, and its skills as rivals with which they are faced. After that, they will explore how customers like the product and what they want to be presented to them. Okay, considering the business climate as Oreo's promotional policy, which depends heavily on content production, they will follow their approach. Promotion is an umbrella term for the advertisement, which helps the product reach its consumer by arranging an exhibition, providing direct mail, and attractive packaging techniques. Effective ads are meant to alter prospective consumers' perception or increase their understanding; information about the product will lead them to purchase the product. As an organization that sells snacks in many countries, they must create a solid promotional plan. That would allow Oreo to gain positive customer reviews. The coupon is one of the deals used by Oreo. In the food stores and on the website, Oreo gave a voucher at the sampling stations. They are now running seasonal advertisements to use the organization's media calendar (www.ETBrandEquity.com, 2020). Oreo is mindful that price and 
delivery may not necessarily be the primary consideration when planning to enter foreign markets. To manage current and future global growth, Oreo uses a marketing blend, including commodity identification, advertising, and promotion. Market segmentation is characterized as a mechanism by which a customer category has similar attributes, needs, or habits, to choose one or more segments for a distinct marketing mix. The market segmentation, multiple businesses are willing to reach their target customers best, which is why many organizations are devoting a great deal of time and focus to particular markets (Hawkins \& Mothersbaugh, 2010).

Next, the industry is divided into separate regional units by geographic segmentation. For example, Malaysia, which has passed fast, has a healthy cookie industry situation. This is because coffee reflects the tradition of cookies. Malaysians will then go through coffee and hear about the world of cookies ("Our brands | Mondelēz Int," n.d.). We see that Mondelez, Oreo often respond with their creative marketing tactics. In the recent pandemic, we know that it released its '\# AtHomewithOreo' digital campaign to encourage customers to stimulate their creative Oreo cookies to fuel innovation (Confectionerynews.com, 2020). The company tries to incorporate a dosage of fun into this modern standard through operation and competitions, which have a unique tendency to help people stay linked. It makes the brand closer to its consumer, and it is one of the reasons for its success (Confectionerynews.com, 2020).

\section{Strategic Focus, Mission, Vision, Values}

Few are the international companies with a high level of customer interaction from digital platforms. A prime example of this is the Oreo Cookie, which, with its combination of ingenuity, smartness, and engagement with consumers, has managing to retain an increasing number of people on its various online platforms, but which has also received a mostly positive reception. This business shows that the opportunity to react to emerging developments and incorporate multiplatform technology enables users to impact new and creative messaging and is mirrored in more than 100 years of cookies history. Mondelēz has more than 40 plants worldwide, and its center of excellence for producing chocolate is in Brazil, a country that will export the product to the USA. The Brazilian plant can ship to 10 countries, such as Argentina, the United States, Chile, Morocco, Costa Rica, and Colombia. The company has a presence in more than 800,000 points of sale, and, in a first-year, Oreo chocolate could reach 700,000 of these commercial spaces. The company has adapted to the market, as not to affect its operation. That was the case with the energy reform enacted in the current trends, such as promoting healthy lifestyles, product innovation, responsibility in advertising issues, and leadership in the communication of balanced diets. In addition, that includes snacks that brought taxes on sweets such as chocolate due to their high caloric content. One of the aspects that characterize a successful brand is the fact that other brands want to ally with it and, through co-branding strategies, launch products that, in a certain way, allow them to leverage their reputation and fame to reposition or reinforce their positioning. All this is also the logical benefit of allying with a widely accepted brand in terms of the sales potential and the attractiveness generated in the category, putting a widely recognized label. Apart from being able to say that this rule is fulfilled in the case of a brand like Oreo, the fact that over time has become one of the most famous snacks worldwide that helped to create new products. It could either be on its own or from the same alliances; we talked about taking advantage of the successful concept of their cookie and knowing how to adapt it to other similar or substitute products. Success preceded it to this day, and the great affection that people profess towards this brand includes children to the elderly. Many do not know that its history contains a certain air of controversy that shows that not everything has been rosy throughout the more than one hundred years it has been on the market. Even in the 20th century, the brand has managed to keep this situation at bay and prevent it from directly impacting its image to the point is unaware of this issue and more. 
It has become a beloved brand in different places and countries where it is present through very well-executed marketing.

\section{Findings and Conclusions}

The analysis presented some exciting findings. It was found that about $76 \%$ of the respondents preferred ice cream to any other kind of snack as they consumed ice cream very often. It refers to the fact that sweet snacks are chosen over savory snacks. Other popular snack food items included pretzels and non-chocolate candy. Surprisingly about $42 \%$ of the respondents ate vegetables very often. But when it came to fruits, only $3 \%$ ate them often as snacks.

I also found that taste was the most significant factor in satisfaction; almost $50 \%$ of the respondents found the taste to be more critical even when factors like quality, calorie count, sugar content, etc., were included. This represents that individuals eat snacks for comfort and often overlook the technicalities and facts if the taste is well adjusted. On the other hand, $36 \%$ also found flavors to be the most important determinants of satisfaction. Though $47 \%$ found the brand to be necessary, it was not significantly influential on their choice. Gluten-free status was regarded as too unimportant by about $17 \%$ of the respondents.

Another finding suggests that $62 \%$ of the respondents prefer Keebler to other brands like Oreo, Snickers, and Kit Kat. The least liked brand was kit Kat, with $48 \%$ moderately disagreeing with it. In addition, in a close second to Keebler, Oreo had about $40 \%$ of respondents agreeing. When the respondents were asked for snack foods they consumed in the last four weeks, $52 \%$ respondent that they ate KitKat often. This might be caused due to the availability and cheaper price point of Kit Kat.

About $80 \%$ of the respondents were found to consume cookies very often. That reinforces our previous finding that people prefer sweet snacks to savory ones. About $83 \%$ consumed non-chocolate candy very often. That tells us that non-chocolate candy has more appeal among the respondents than chocolate ones, as only $26 \%$ consumed chocolate candy sometimes. The fact is reinforced further when it is found that $86 \%$ of the respondents find sugar to be an essential factor in their snack foods.

However, $48 \%$ of the respondents were found to consume potato chips often, which informs us that a significant portion is inclined towards savory snack foods due to their availability and the wide range of available flavors.

Surprisingly only $4 \%$ of the respondents eat fruits often. It is alarming as it shows that young adults (as the average age of respondents is 28) are reluctant to have a healthy diet when it comes to snacking. To conclude, it can be inferred that most of the traits observed among respondents suggest that snack food is consumed for comfort rather than need. Moreover, people find sugary snack foods to be more comforting than savory or non-sugary ones.

\section{Ethics}

In the business community, ethics at work has gained even more focus lately, so it is a priority that its ethical principles align with its staff-all to enhance the working climate. Workplace principles and integrity are essential to keeping a safe work environment and order. Every employee of the organization can behave with its principles and individual beliefs. It cannot differentiate personal ethics and work ethics. It significantly affects the organization's performance. The above would essentially contain the ethical principles that the organization assumes and the activities, priorities, and image in society. In this particular situation, my Code of Labor ethics regulates the company's code of professional ethics. The categories of conduct 
should be indicated: coerced, optimal, preferred, and forbidden. In order to render this behavior, which would rely on the business, the text must be straight enough.

The fines must be equal to the actions measured and must reward good behavior. This case is in the Privacy Arrangement. A way to work ethics when we have potential partners in our industry or recruit a team member or associate, we need our details to be protected and follow the profile of what we are looking for. A confidentiality arrangement should be agreed upon for this reason. The privacy arrangement is an agreement in which a person undertakes not to disclose information or data used as a relative or participant in the production of his activities. To create a working code and to interpret it Ethical theory and business practice, 2019). This arrangement guarantees that no details of significant significance is revealed and it is deemed essential to an organization. During his contract's length, the employee undertakes to keep all knowledge that he has access to the company classified and private. Contracts or privacy arrangements are a central part of every organization. They must be carried out in a timely and sufficient way to ensure security and privacy confidentiality between the parties. They launched an aggressive new growth strategy this fall that includes a bold plan to revamp old brands and launch new fashion businesses. After years of cost-cutting efforts, the move comes after years that hurt its snack sales by keeping in mind the proper business operation. The movement has been further intensified (Ethical theory and business practice, 2019). The proposal I get from the executive of another company is both illegal and unethical. Our corporate security of information and ethics policy directs their employees in their company around the world to comply with all relevant laws and regulations. It also underlines how important it is for us because their trust and faith are crucial to their growth, behave in integrity, and make ethnic decisions for their company, shareholders, employees, and customers. Corporate ethics is an applied and ethical conduct that discusses ethical, moral, and business values and issues arising. I refer on behalf of all individuals and the whole organization to all areas of corporate practice. A business ethics concept means recognizing the distinction between right and wrong and choosing to do right Ethical theory and business practice.

\section{Corporate Social Responsibility}

In the past, the company's strategic aim was to build a relationship with its customers and allow them to revive the kid we all bear with the renowned ritual; twist, taste, and dip; all this turns a simple galley into an enjoyable experience. The harm theory notes that individuals should be able to act without hurting someone else. In neoclassical economics, the usefulness of desires is referred to as pleasure, whereas moral theory implies enjoyment, no matter if it is perceived. They expressed their willingness to continue contributing to reducing its environmental impact through, for example, making all its packaging recyclable by 2025 . It is based on the fact that each person often acts on the concept of greater happiness in terms of the advantage of the maximum number of people - whether it is alone, group, private or public, and in the field of political legislation. $9 \%$, respectively. Honesty does not just have to tell the truth. "Moral ideal" is an ascription of behavior that strives for a norm that it cannot fully satisfy (operationalize). In this scenario, Mondelēz International detailed that it has improved its best-selling brands' nutrition and ingredient profile. To this end, the company teaches organic farming methods to tackle climate change. Paternalism is an impairment of another's rights or autonomy to achieve the benefit or to avoid damage to that person. Legality requires responsibilities under the statute and common law, both statutory and civil (Ethical theory and business practice, 2019).

In the next years and supporting thousands of cocoa growers, Cocoa Life plans to spend $\$ 400$ million. In ethics, an idea is a principle or a value proposed as a model of perfection to follow. Inside and regardless of how long they last, big corporations develop robust marketing campaigns to retain intimate relations with their customers behind the most recognizable brands in the world. The belief in ideals is called ethical 
idealism. Cocoa Life has been developed to promote farmers' eco-friendly production of Cocoa. Also, a very contentious topic occurs in a variety of areas. Spontaneous and spontaneous moments might transform into memorable moments. The "ideal" is a comparison model that daily practice should follow as a guideline, but it does not have to be fulfilled. It can be said that, among other causes, the continuous approach in search of certain ideals has participated in what is commonly called the progress of humanity. The software also helps neighborhoods customize their ventures while protecting the local ecosystems to improve their small enterprises. It would certainly be illegal where prosecutions include committing a criminal offense. Oreo starts a new global equity strategy to continue to create strong ties. In principle, only human beings can have ideals or develop behavior in search of objectives. "Utilities," usually concerning the wellbeing of human beings, are described in different ways. Via this strategy, they plan to increase the quality of Cocoa while controlling and preserving damaged forests. We are just about who we are for ourselves and other people, what we want to live the most simple life, and what we need to live. Oreos has revealed that its signature cookies will only use organic Cocoa this month. The theory of justice may be defined through a fair trial between opposing cases as the moral imperative to act. It is the property of recognizing, upholding, and respecting one's actions in the sense of politics. The organization expects that this will allow them to expand their environmental-friendly procurement activities rapidly. For example, paternalism is required in daily life by laws that allow for seat belts, motorcycle helmets, and forbid some medicines. The principle or rule of charity refers to a regulatory statement that offers a moral duty to support others and let them foster their significant and valid needs, mostly through avoiding or removing potential harms. Via its Cocoa Life scheme, you can use Cocoa from organic growers. As such, justice, rights, and equity are related.

Self-determination or self-governance is the skills of a person. The consequence of an operation, less the pain of anyone involved in this action, is an amount of all enjoyment. Thus, the company has reduced sugar levels by $1 \%$ in brands such as Oreo and Milk and saturated fat and sodium by $1 \%$ and 0 . This is the case for the Mondelez International multinational snacks corporation and its Oreo brand, the most well-known cookie globally, which has been in the industry for more than 100 years. It is an unattainable but infinitely approximate state (Ethical theory and business practice, 2019).

\section{Operational Definitions}

\subsection{Marketing and Marketing Management}

Marketing helps to meet the human desire and all kinds of social needs. In a word, we can say that marketing meets probability. On the other hand, we can define marketing as the process of communication, delivering, exchange offerings that create value to the customer, clients, partners, and society at large (Kotler \& Keller, 2011, p.5). So, marketing management is part of the science of choosing the target market and getting, keeping, growing customers through creating value. Marketing can be defined as a social and managerial term where marketing plays roles in society, and marketing focus on buying and selling goods in terms of profit is for the organizational period.

\subsection{Needs, Wants, and Demands}

Humans always have some basic requirements of their day-to-day life, such as air, food, clothing, shelter, security, and all those considered needs. The human also has some conditions for education, recreation, and entertainment. So, these needs became demand when they are subjected to meet some specific object. For example, Bangladeshi customers need food but may also want beef and chicken. Our society shapes what we want. When humans can pay for some selected goods or services, then that 
became a demand. For example, many people want an iPhone, but not all of them can afford that; those who can afford that then it became a demand for that specific group of people (Kotler \& Keller, 2011, p.9).

\subsection{Marketing Concept and Holistic Marketing}

The marketing concept first came in mid-195s as a customer-centered and respond philosophy. The main concern about this marketing concept is to find the right customer for the right product. For example, the Food hub in India makes foods for the customer and provides an option for the customer to select their specific food and make it according to their choice. The marketing concept is essential for the organizational goal and target customer base (Kotler \& Keller, 2011, p.18).

The holistic marketing concept focuses on the development, design, and implementation of a marketing program. It helps the organization to recognize its breadth and independence. It mainly focuses on that everything does matter in marketing (Kotler \& Keller, 2011, p.18-19).

\subsection{Social Responsibility Marketing \& Corporate Social Initiatives}

There is some number of sources in the society, and those sources force a company to practice higher corporate social responsibility such as the fulfillment of customer expectation and desire needs, evolving employees' goal and ambition maintain government legislation and pressure, investors interest and social criteria, media security and so on. Virtually all the firms are more active to focus on social responsibility so that they come to know how they will treat their customer, computations, government, investors. Rising socially responsible marketing calls for marketing a three-pronged attack that relies on proper legal, ethical, and socially responsible behavior. Corporate social responsibility is vital for a firm to run its business (Kotler \& Keller, 2011, p.629-630).

\subsection{Marketing Mix (4P's)}

The marketing mix is the set of tactical marketing tools: product, price, place, and promotion, that the firm blends to produce the response it wants in the target market. Product refers to the combination of goods and services the firm offers. The place refers to the place where the service or goods will be available, the price indicates how much the customers are willing to pay for a product, and the promotion indicates how the product will attract the customer and the ay of communication. The work includes; product variety, quality, design, feature, brand name, pacing, size, service, warranties, return. The price includes; coupon, discount, allowance, credit term. The promotion consists of; sales force, sales promotion, advertisement, direct marketing, and the place includes; channel, coverage, location, inventory, and transport (Kotler \& Keller, 2011, p.18)

\subsection{Core Competency and Competitive Advantage}

Most of the companies run traditionally with their strategies and resources. For example, labor power, materials, machine, information, and energy. They also focus on natural resources. Nowadays, most firms focus on product development, design, and marketing. Core competencies have mainly three characteristics,

1. Competitive advantage (customer benefits)

2. Market application 
3. Difficult for computations to imitate

Competitive advantage also occurs to companies that process distinctive capabilities or do best in the border business process. It mainly indicates how well a business derives from its core competencies and distinctive capabilities into a highly active system (Kotler \& Keller, 2011, p.35)

\subsection{Mission Statements and Major Characteristics}

A mission statement is a statement of the organization's reason for being, its purpose - what it wants to accomplish in the broader environment. So, each business needs to define its selected and specific mission within the border company mission. On the other hand, the business mission statement does not attempt to win business from a smaller part or venture into non-lighting products. The business mission has various features, and the most important is external and internal analysis. With the external and internal investigation, a business $\mathrm{r}$ firm can understand its weakness, strength, opportunity, and threats, and they can run accordingly. Some other important characteristics are goal formulation, strategy formulation, program formulation, implementation, and feedback (Kotler \& Keller, 2011, p.38,48-49). Significant elements are below:

1. They focus on a limited number of goals.

2. They stress the company's significant policies and values.

3. Major competitive spheres within the company.

4. They take a long-term view.

5. They are short, memorable, and meaningful.

\subsection{Diversification, Integrative, and Intensive Growth}

For the development of a firm, their first option is to identify the opportunities within their current business that they are running (intensive opportunities), the second in to identify opportunities to build their business related to existing business (integrative opportunities), and the last is to identify opportunities to add attractive unrelated business (diversification opportunities). The diversification growth makes the scene when good opportunities exist outside the present business and industry, the industry is highly engaging, and the company has the right mix of business strength to succeed (Kotler \& Keller, 2011, p. 42-45).

\subsection{SWOT Analysis}

SWOT analysis is the overall identifications of the company's strengths, weaknesses, opportunities, and threats. A company should evaluate all these elements to run a smooth business. The SWOT analysis is divided into two types one is internal, and another one is external. One of the primary important things is threats that the company should be aware of, like the possible forces that could harm the company. And weakness meaning is to what are the things that a company should I improve inside their business for the betterment and more profit (Kotler \& Keller, 2011, p. 48-51).

\subsection{Population Growth, Age and Ethnic Mix}

Currently, world population growth is explosive, and population growth is a part of the demographic environment. Demographic developments often at a predictable pace. The primary market is a population that includes the population's size and growth rate in a different place, city, region, and nation. Age and 
ethics mix is a part of this demographic environment too. A growing population does not mean a growing market unless there is enough purchasing power. There is a global Trent towards the aging population (Kotler \& Keller, 2011, p.75).

Managers generally divide the population into six groups: preschool children, school-age children, teens, young adults age 20-40, middle-aged aged 40-65, and older adults age 65 and older. Some marketers focus on cohorts. Ethnic and racial diversity varies from country to country(Kotler \& Keller, 2011, p.76-77).

\section{Market Demand, Share, Forecast and Potential}

Every company needs to understand the environment and conduct research, which can help identify more firms' opportunities. Every company must measure and forecast the size, growth, and profit potential for each new option. Sales forecasts are prepared by marketing are used by financing to raise cash for each investment and operations. The first step in evaluating marketing opportunities is to measure market demand. The market potential is the limit approached by market demand by industry marketing expenditure approach infinity for a given market environment (Kotler \& Keller, 2011, p.85$88)$.

\subsection{Company Demand, Forecast, and Potential}

Company demand is the company's estimated share of market demand at alternative levels of the company's marketing effort in each period. It depends on some marketing forces such as product, service, price, and communication. On the other hand, the company demand depends on the relative scale and effectiveness of its market expenditures. Company sales potential is the sales limit approached by company demand as company marketing effort increases comparable to those competitions. The absolute limit of company demand is, of course, the marketing potential (Kotler \& Keller, 2011, p.87).

\subsection{Focus Group Research}

Basically, during marketing research, a group of 6 to 10 people are selected based on demographic, psychographic, or based on other conditions and brought together to discuss various topics related to the research and interest. All the participants usually are paid little attention. A professional marketing researcher provides some basic questions, and they discuss it within a group. Sometimes the modulator records the entire discussion and later works on research. It is usually useful for the exploratory step, but researchers avoid generalization from the whole market participants because the sample size is too small(Kotler \& Keller, 2011, p.101-102).

\subsection{Survey Research}

Surveys are mainly done to assess peoples' and customers' knowledge, beliefs, preferences, and satisfaction and to measure these magnitudes of a general population. Surveys can be done in many ways, such as it can be in a questionnaire form or face to face question-answer session. For example, researchers can stop people on the street or in a spotting mall and ask them a general question about selected brands or services. Some kinds of surveys are e-mail, web-based, online, by phone, mail, or in person. Companies must combine all the information all together. For example, san Francisco-based wells Fargo bank collects more than 50,000 customer surveys each month through its bank branch (Kotler \& Keller, 2011, p.103) 


\subsection{Marketing Metrics}

A firm employ needs various measures to assess marketing effects. The marketing mix is the set of standards that quantify, compare, and interpret their marketing performance and measure them in marketing. There are so many marketing measures, but marketers choose one more based on issues they face during their marketing process. Marketing accountability also means that marketers must more preciously estimate the effects of different marketing investments. Marketing mix model analyses data from a variety of sources. Marketing modeling focuses on incremental growth instead of baseline sales or long-term effects (Kotler \& Keller, 2011, p.114-116).

\subsection{Customer Perceived Value \& Value Proposition}

Customer perceived value is the difference between prospective customer evaluation of all the benefits and the cost of different offerings and all the perceived alternatives. So, customer perceived value is thus based on the difference between services the customer gets and the price he/she assumes for a different choice. The marketers can raise the importance of the customers by raising economic, functional, or emotional benefits. Mainly customers choose between two value offerings. The customer value is the whole proposition that a company promised to deliver (Kotler \& Keller, 2011, p.124-126).

\subsection{Perception, Selective Attention, Selective Distortion, Selective Retention}

Customer perception is how we select and intercept information to create a meaningful picture of the world. It depends not only on one physical stimulus but also on the stimulus's relationship to the surrounding environment and condition within each of us. Customer perception can vary from person to person, depending on their interest level. Selecting attention is the allocation of processing capacity to some chosen stimulus. Sometimes marketers can not recall all the exposed information. Because of selective retention, they are more likely to remember a good point about a product that customers would likely forget about the product. Selective retention also works to the advantage of healthy products (Kotler \& Keller, 2011, p.161-162).

\subsection{Consumer Buying Process}

The consumer buying process is the basic psychological process that they have reviewed plays an important role in consumers' actual buying decisions. Who, what, when, why, how, where is the question mark that comes into customers' minds before deciding on buying a product or service. Giant companies try to understand customers buying decision processes fully. (Kotler \& Keller, 2011, p.166-167).

\subsection{Buying Situations}

The business buyer faces many decisions in making a purchase. Many depend on the complexity of the problem being solved, the newness of the buying requirement, the number of people involved, and the time needed. A new task rebuys purchaser to buy a service or product for the first time. The greater the cost and risk, the larger the number of participants (Kotler \& Keller, 2011, p.185-186).

\subsection{Buying Center Roles}


In the buying center, all organization members pay any of the following seven roles in their purchase decision process: initiators, users, influencers, deciders, approvers, buyers, and gatekeepers. Initiators or other organizations who request something to be purchased. Sometimes they provide ideas and add value to the product that could be purchased by others. People who have the power to prevent sellers or information from reaching members of the buying center are called gatekeepers (Kotler \& Keller, 2011, p.188-189).

\subsection{Demographic Segmentation}

In demographic segmentation, we mainly divide the market into various aspects such as age, family size, family life, gender, income, occupation, religion, race, generation, nationality, and social class. One of the main reasons for this demographic segmentation is that they are often associated with customers' needs and wants. Demographic segmentation is straightforward to measure. Even when we describe the target in the non-demographic term, we may need the link back to demographic characteristics to estimate the perfect size (Kotler \& Keller, 2011, p.216-217)

\subsection{Psychographic Segmentation (VALS)}

Psychographic segmentation is the science of using psychology and demographics to better understand the consumers. In this segmentation, buyers are divided into different groups based on their traits, lifestyle, or values. People within the same demographic group can exhibit very different psychological profiles. One of the most important commercially available classification systems used in this segmentation is VALS.VALS signifies values and lifestyle and classifies U.S adults into eight primary groups based on a questionnaire response (Kotler \& Keller, 2011, p.225-227).

\subsection{Segmentation Criteria}

Not all the segmentation is useful. If we can divide buyers of table salt into blond and brunette customers, but then hair could be matter. So, for helpful market segmentation, there are five critical criteria, and they are given below.

Measurable: The size, purchase power, and characteristics of the segment to be measured.

Sustainable: The segment must be large and profitable enough to serve. A segment should be the large possible homogenous group worth going after with a tailored marketing program.

Accessible: the segment can be effectively reached and served.

(Kotler \& Keller, 2011, p.231-232).

\subsection{Branding, Brand Equity, \& Brand Promise}

American marketing association defines a brand as a name, term, sign, symbol, or design or combination to identify the goods or services of one seller or group of sellers and differentiate them from competitors. A brand is thus a product or service whose digestion determines in the same way firm order product or service design to satisfy the same need (Kotler \& Keller, 2011, p.241). So branding is also endowing product or service with the power of the brand.

Brand equity is the benefit of endowed on products or services. It may be reflected in the way consumers think, feel, and act concerning the brand and the prices, market share, and profitability of the brand command. Marketers and researchers use various ways to study brand equity; it also lies in what 
customers read, think, heard, learned, thought, and feels about the read (Kotler \& Keller, 2011, p.243). A brand promise is the marketer's vision of what the brand must be and do for the customer. Most customers will expect what the company promised to give (Kotler \& Keller, 2011, p.244).

\subsection{Brand Reinforcement and Brand Revitalization}

The market can reinforce brand equity by consistently conveying the brands meaning in terms of what the product is represented, what core benefits are there, what needs are satisfied, and how it makes the product superior. The first thing to revitalize a brand is to understand what the sources of brand equity were. First, any new development in the marketing environment can affect brand fortunes, positively or negatively. Sometimes the actual marketing program is the source of the problem because it fails to deliver what the brand promises (Kotler \& Keller, 2011, p.258-259).

\subsection{Brand Extensions}

With the changing technology, most of the brad extended their product like, either; they came up with a new product or benefit to their existing product. Most new products are, in fact, line extension, typically 80 t0 90 percent in any one year-moreover, many of the new successful new products as rated by various sources. For example, among the most successful brand extension in supermarkets in 2018 were Dunkin doughnut coffee. Neither a few new products are introduced each year as a new brand (Kotler \& Keller, 2011, p.263-264).

\subsection{Positioning and Competitors}

Positioning is the act of designing a company offering and image to occupy a distinctive place in the target market's minds. The main goal is to positively set up the brand in the customer's minds that create value. A good brand positioning helps guide marketing strategy by identifying the brand essence and the brand goal. A perfect starting point is defining a competitive frame of reference for brand positioning is to determine category membership. The range of companies' actual and potential competitors can be much broader than the obvious (Kotler \& Keller, 2011, p.276-277).

\subsection{Points of Difference and Points of Parity}

Points of difference are the attributes or benefits that consumers strongly associate with a brand. Positivity evaluates a belief they could not find to the same extent as other companies or brands. An Association that makes a point of difference may be based on virtually any attributes or benefits. A strong brand might have multiple points of difference. These associations come in two basic categories: category and competitive (Kotler \& Keller, 2011, p.280-281).

\subsection{Marketing Communications Mix (8 Modes of Communication)}

Marketing communication is how a firm attempts to inform, persuade, and remind consumers directly or indirectly about the product or services they are offering. In the case of marketing, communication represents all the voices of the company and its brand. Marketing communication also works for consumers when they how, why a product is used, where, and when. There are eight types of marketing communication mix, and they are below. 
(Kotler \& Keller, 2011, p.476-478).

Media selection is finding the most cost-effective media to deliver the desire number and type of exposure t0 the target audience. The press could help me with online and offline services, but the main focus is to reach the target audience's attention.

Reach The number of different persons or households exposed to a media schedule at least once during a specific period.

Frequency: The number of times within the specific period that an average person or household is exposed to the message.

Impact: The qualitative value of an exposure through a given medium (Kotler \& Keller, 2011, p.511).

\section{Acknowledgments}

I am grateful to Professor Myles Bassell for guiding me in the preparation of this research report. Professor Myles Bassell's experience in conducting research, expertise in writing research reports, insights regarding the snack food industry, and knowledge of the Oreo brand have been helpful, and sources of inspiration.

\section{References}

Bublitz, M.G. and Peracchio, L.A., 2015. Applying industry practices to promote healthy foods: An exploration of positive marketing outcomes. Journal of Business Research, 68(12), pp.2484-2493.

Cabañas, B., 1992. A Marketing Strategy for Resort Conference Centers: Operators of resort conference centers need to take a strategic approach to marketing. In this example, one conference center operator is using computer technology to sales and marketing. Cornell Hotel and Restaurant Administration Quarterly, 33(3), pp.45-49.

Chacon, V., Letona, P. and Barnoya, J., 2013. Child-oriented marketing techniques in snack food packages in Guatemala. BMC Public Health, 13(1), pp.1-6.

Guo, M., Lu, L., Sheng, L. and Yu, M., 2018. The day after tomorrow: Evaluating the burden of Trump's trade war. Asian Economic Papers, 17(1), pp.101-120.

Hasibuan, S., 2015. SMEs development strategy for competitive and sustainable typical local snacks of Banten province. International Journal on Advanced Science, Engineering and Information Technology, 5(6), pp.410-414.

Hawkins, D. I., \& Mothersbaugh, D. L. (2010). Consumer behavior: Building marketing strategy. Boston: McGraw-Hill Irwin,.

Hult, G. T. M., \& Ketchen, D. J. (2017). Disruptive marketing strategy. Ams Review, 7(1-2), 20-25.

Kanten, I. K., \& Darma, G. S. (2017). Consumer Behaviour, Marketing Strategy, Customer Satisfaction, and Business Performance. Jurnal Manajemen Bisnis, 14(2), 143-165.

Kotler, P., \& Keller, K. L. (2011). Analyzing business market/ buying situation. InMarketing Management (p.185-186). One Lake Street 07458, New Jersey: Prentice-Hall

Kotler, P., \& Keller, K. L. (2011). Analyzing business market/ The buying center. InMarketing Management (p.188-189). One Lake Street 07458, New Jersey: Prentice-Hall

Kotler, P., \& Keller, K. L. (2011). Analyzing customer market/ The busying decision process. InMarketing Management (p.166-167). One Lake Street 07458, New Jersey: Prentice-Hall

Kotler, P., \& Keller, K. L. (2011). Analyzing customer market/Perception, Selective Attention, Selective Distortion, Selective Retention. InMarketing Management (p.161-162). One Lake Street 07458, New Jersey: Prentice-Hall

Kotler, P., \& Keller, K. L. (2011). Collecting information and for casting demand/ The demographics environment. In Marketing Management (p.75-77). One Lake Street 07458, New Jersey: Prentice-Hall.

Kotler, P., \& Keller, K. L. (2011). Collecting information and for casting, demand/ market Demand, Share, Forecast, Potential. InMarketing Management (p.85-88). One Lake Street 07458, New Jersey: Prentice-Hall. 
Kotler, P., \& Keller, K. L. (2011). Collecting information and for casting demand/ Company Demand, Forecast, and Potential. In Marketing Management (p.87). One Lake Street 07458, New Jersey: Prentice-Hall.

Kotler, P., \& Keller, K. L. (2011). Conducting marketing research/ Research approaches. In Marketing Management (p.101-102). One Lake Street 07458, New Jersey: Prentice-Hall

Kotler, P., \& Keller, K. L. (2011). Conducting marketing research/ Research approaches. In Marketing Management (p.103). One Lake Street 07458, New Jersey: Prentice-Hall

Kotler, P., \& Keller, K. L. (2011). Conducting marketing research/ Marketing metrics. In Marketing Management (p.114-116). One Lake Street 07458, New Jersey: Prentice-Hall

Kotler, P., \& Keller, K. L. (2011). Creating brand equity/Brand Reinforcement and Brand Revitalization. InMarketing Management (p.258-259). One Lake Street 07458, New Jersey: Prentice-Hall

Kotler, P., \& Keller, K. L. (2011). Creating brand equity/Branding, Brand Equity, \& Brand Promise. InMarketing Management (p.243 245). One Lake Street 07458, New Jersey: Prentice-Hall

Kotler, P., \& Keller, K. L. (2011). Creating brand positioning/ Positioning and competitors. InMarketing Management (p.276-277). One Lake Street 07458, New Jersey: Prentice-Hall

Kotler, P., \& Keller, K. L. (2011). Creating brand positioning/ Point of difference and point of parity. InMarketing Management (p.280281). One Lake Street 07458, New Jersey: Prentice-Hall

Kotler, P., \& Keller, K. L. (2011). Creating customer value, satisfaction, and loyalty/, Customers perceived value and values proposition. In Marketing Management (p.124-125). One Lake Street 07458, New Jersey: Prentice-Hall

Kotler, P., \& Keller, K. L. (2011). Designing and Managing Integrated Marketing Communications/ Marketing communication 8 mix. InMarketing Management (p.476-478). One Lake Street 07458, New Jersey: Prentice-Hall

Kotler, P., \& Keller, K. L. (2011). Developing marketing strategies and plan/Core Competency and Competitive Advantage. In Marketing Management (p. 35). One Lake Street 07458, New Jersey: Prentice-Hall.

Kotler, P., \& Keller, K. L. (2011). Developing marketing strategies and plan/ Business mission statement and major characteristics. In Marketing Management (p.38, 48-49). One Lake Street 07458, New Jersey: Prentice-Hall.

Kotler, P., \& Keller, K. L. (2011). Developing marketing strategies and plan/ Assigning resources to each SBU. In Marketing Management (p.42-45). One Lake Street 07458, New Jersey: Prentice-Hall.

Kotler, P., \& Keller, K. L. (2011). Developing marketing strategies and plan/ SWOT analysis. In Marketing Management (p.48-51). One Lake Street 07458, New Jersey: Prentice-Hall.

Kotler, P., \& Keller, K. L. (2011). Identifying market segment and target/ Demographic segmentation. InMarketing Management (p.216217). One Lake Street 07458, New Jersey: Prentice-Hall

Kotler, P., \& Keller, K. L. (2011). Identifying market segment and target/ Psychographic segmentation (VALS). InMarketing Management (p.226-227). One Lake Street 07458, New Jersey: Prentice-Hall

Kotler, P., \& Keller, K. L. (2011). Identifying market segment and target/ Segmentation criteria. InMarketing Management (p.231-232). One Lake Street 07458, New Jersey: Prentice-Hall

Kotler, P., \& Keller, K. L. (2011). Managing mass communication/ Media selection, Reach, Frequency, and Impact. InMarketing Management (p.511). One Lake Street 07458, New Jersey: Prentice-Hall

Kotler, P., \& Keller, K. L. (2011). Tapping into global markets/ social responsibility and corporate initiatives. In Marketing Management (p. 629-630). One Lake Street 07458, New Jersey: Prentice-Hall.

Kotler, P., \& Keller, K. L. (2011). Understanding Marketing Management. In Marketing Management (p. 5). One Lake Street 07458, New Jersey: Prentice-Hall.

Kotler, P., \& Keller, K. L. (2011). Understanding Marketing Management/ Marketing concept and holistic marketing concept. In Marketing Management (p. 18-19). One Lake Street 07458, New Jersey: Prentice-Hall.

Kotler, P., \& Keller, K. L. (2011). Understanding Marketing Management/ Marketing mix and 4ps of marketing. In Marketing Management (p. 18). One Lake Street 07458, New Jersey: Prentice-Hall

Kotler, P., \&amp; Keller, K. L. (2011). Understanding Marketing Management/ Needs, wants \&amp; Demand. In Marketing Management (p. 9). One Lake Street 07458, New Jersey: Prentice-Hall.

Levine, J., 1999. Food industry marketing in elementary schools: implications for school health professionals. Journal of Sch ool Health, 69(7), pp.290-290.

Loy, J. E., Rohde, H., \& Corley, M. (2019). Real-time social reasoning: the effect of disfluency on the meaning of some. Journal of Cultural Cognitive Science, 3(2), 159-173.

Mondelēz International, Inc. 2020. Oreo Cookie Title. [online] Available $<$ https://www.mondelezinternational.com/Our\%20Brands/Oreo $>$ [Accessed 24 September 2020].

Monteiro, C.A., Gomes, F.S. and Cannon, G., 2010. The snack attack. American journal of public health, 100(6), pp.975-981.

Morgan, N. A., Whitler, K. A., Feng, H., \& Chari, S. (2019). Research in marketing strategy. Journal of the Academy of Marketing Science, 47(1), 4-29.

Olson, E. M., Slater, S. F., Hult, G. T. M., \& Olson, K. M. (2018). The application of human resource management policies within the marketing organization: The impact on business and marketing strategy implementation. Industrial Marketing Management, 69, 6273

Patrutiu-Baltes, L. (2016). Inbound Marketing-the most important digital marketing strategy. Bulletin of the Transilvania University of Brasov. Economic Sciences. Series V, 9(2), 61.

Reddy, S. K. (2014). An Oreo with Chinese characteristics. 
Rutz, O. J., \& Watson, G. F. (2019). Endogeneity and marketing strategy research: an overview. Journal of the Academy of Marketing Science, 47(3), 479-498

Sarkar, S. and Costa, A.I., 2008. Dynamics of open innovation in the food industry. Trends in Food Science \& Technology, 19(11), pp.574-580.

Wiist, W.H., 2011. The corporate play book, health, and democracy: the snack food and beverage industry's tactics in context. Sick societies: Responding to the global challenge of chronic disease, pp.204-216.

Zuhdi, S., Rainanto, B. H., \& Apriyani, D. (2020, May). Analysis of Co-Branding Strategy to Improve Company's Competitive Power (Case Study on Walls Selection Oreo). In 2nd International Seminar on Business, Economics, Social Science and Technology (ISBEST 2019) (pp. 146-149). Atlantis Press. 